\title{
Kepatuhan Jumantik Rumah dalam Mengisi Kartu Jentik Sebagai Upaya Surveilans Vektor DBD di Kecamatan Pondok Aren Kota Tangerang Selatan
}

\section{House Larva Monitoring Obedience to Fill Control Form As a Vector Surveillance Effort in Pondok Aren Sub District South Tangerang}

\author{
Hubullah Fuadzy*, Heni Prasetyowati, Endang Puji Astuti \\ Loka Penelitian dan Pengembangan Kesehatan Pangandaran, Badan Litbang Kesehatan, \\ Kementerian Kesehatan RI \\ Jalan Raya Pangandaran Km 3, Babakan, Pangandaran, Jawa Barat, Indonesia \\ *E_mail: hubullah_fy@yahoo.com
}

Received date: 18-05-2020, Revised date: 14-09-2020, Accepted date: 11-11-2020

\begin{abstract}
ABSTRAK
Kartu jentik pada program G1R1J dapat digunakan sebagai media surveilan vektor. Penerapan kartu tersebut masih mengalami kendala. Studi ini menganalisis kepatuhan Jumantik rumah mengisi kartu jentik di wilayah kasus DBD tinggi dan rendah Kota Tangerang Selatan. Data kuantitatif melalui wawancara menggunakan kuesioner terhadap 268 Jumantik rumah, sedangkan data kualitatif melalui wawancara mendalam terhadap 10 informan terpilih. Variabel karakteristik, pengetahuan, sikap dan tindakan dianalisis menggunakan uji Mann Whitney untuk melihat perbedaan kelompok, sedangkan analisis kualitatif menggunakan Strengtness, Weakness, Opportunity, Threat (SWOT) untuk mengidentifikasi potensi dan motivasi kepatuhan Jumantik rumah. Hasil studi menunjukkan sebagian besar responden adalah perempuan usia produktif. Sebagian besar responden mengetahui bentuk dan manfaat kartu jentik ( $p$-value 0,$101 ; 0,248)$, namun responden tidak mengetahui siapa yang mengisi kartu (p-value 0,636). Hasil tersebut tidak berbeda (signifikan) antara kelompok kasus DBD rendah dan tinggi, hasil ini sama dengan analisis variabel sikap ( $p$-value 0,254 dan 0,636). Hasil analisis tindakan menunjukkan bahwa ada perbedaan praktek rutinitas pengisian dan pemeriksaan kartu jentik antara kelompok kasus rendah dan tinggi ( $p$ value 0,$000 ; 0,005)$ begitupula dengan pelaksanaan sosialisasi G1R1J $(p$ value 0,000). Kepatuhan Jumantik rumah mengisi kartu jentik di wilayah kasus DBD rendah lebih baik dibandingkan di wilayah kasus DBD tinggi. Hambatan dalam pengisian kartu jentik adalah kurangnya sarana, usia lanjut, kelemahan penglihatan, kesibukan, dan lupa.
\end{abstract}

Kata kunci: kartu kontrol, Jumantik rumah, surveilans vektor DBD, Tangerang Selatan

\begin{abstract}
Control form in one house one Jumantik program can be a vector surveillance media. The implementation of the control form has many obstacles. This study described the compliance of Jumantik in filling control form in high and low dengue case area in South Tangerang. Quantitative data were obtained using a closed questionnaire with 268 respondents. Qualitative data were obtained from in-depth interviews with 10 selected informants. Variables in the form of characteristics, knowledge, attitudes and actions were analyzed using the Mann Whitney test to see group differences, while qualitative analysis by identifying potential and motivation for compliance in filling control form which is categorized into Strengtness, Weakness, Opportunity, Threat (SWOT) analysis. The results show that most of the respondents are women who in productive age. Most of the respondents knew the form and benefits of the control form (p-value 0.101; 0.248), but respondents didn't know who filled out the forms ( $p$-value 0.636). These results did not differ significantly between low and high DHF case groups, these results were the same as the analysis of attitude variables (p-value 0.254 and 0.636). The action analysis showed that there were differences in the routine practice of filling and checking control forms between the low and high case groups (p-value 0.000; 0.005) as well as the implementation of G1R1J socialization ( $p$-value 0.000). House larva monitoring obedience to fill control form in areas with low Dengue cases is better than in areas with high Dengue cases. The challenges in filling control form were lack of facilities, old age of staff, visual impairment, busyness, and forgetfulness.
\end{abstract}

Keywords: control card, household Jumantik, vector surveillance, South Tangerang 


\section{PENDAHULUAN}

Demam Berdarah Dengue (DBD) adalah infeksi virus dengue yang ditularkan oleh nyamuk Aedes sp. dan ditemukan hampir di seluruh dunia. World Health Organization (WHO) menyebutkan sekitar 390 juta infeksi dengue terjadi setiap tahun dengan 96 juta kasus menunjukkan manifestasi klinis. ${ }^{1}$ Populasi berisiko penularan virus dengue mencapai 3,9 miliar orang yang tersebar di 128 negara., ${ }^{2,3}$ Lebih dari $70 \%$ populasi berisiko tersebut hidup di wilayah Asia Tenggara dan Pasifik Barat, salah satunya adalah Indonesia. ${ }^{1}$ Ini menunjukkan bahwa DBD menjadi masalah kesehatan masyarakat yang perlu mendapatkan perhatian khusus di Indonesia.

Kota Tangerang Selatan merupakan salah satu wilayah endemik DBD di Indonesia. Kasus DBD di Kota Tangerang Selatan berfluktuasi selama tiga tahun terakhir dan terdapat kecenderungan mengalami peningkatan kasus. Periode tahun 2017-2019 secara berturut-turut jumlah kasus DBD di wilayah Kota Tangerang Selatan yaitu: 245, 484 dan 417. Jumlah kasus tiga tahun terakhir tersebut mengalami penurunan jika dibandingkan dengan kasus tahun 2016 yaitu 655 kasus. $^{4}$ Fluktuasi kasus ini tidak terlepas dari berbagai program yang telah dilakukan oleh Dinas Kesehatan Kota Tangerang Selatan, baik pada aspek tata laksana kasus, surveilans kasus dan vektor, serta pengendalian vektor. Namun, belum seluruh wilayah dapat menerapkan program tersebut secara tepat dan berkelanjutan, sehingga kasus DBD berpotensi meningkat kembali.

Salah satu upaya pengendalian vektor yang digalakkan oleh Dinas Kesehatan Kota Tangerang Selatan adalah penerapan program Gerakan Satu Rumah Satu Jumantik (G1R1J). Program ini telah dilaksanakan sejak tahun 2016 hingga sekarang, dengan menitikberatkan pada upaya pemberdayaan masyarakat untuk melaksanakan Pemberantasan Sarang Nyamuk (PSN) secara mandiri di rumah tinggalnya masing-masing. Gerakan Satu Rumah Satu Jumantik didefinisikan sebagai peran serta dan upaya pemberdayaan masyarakat. Kegiatan ini melibatkan setiap anggota keluarga untuk melakukan pemeriksaan, pemantauan dan pemberantasan jentik nyamuk. Hal ini dilakukan sebagai bentuk pengendalian penyakit tular vektor khususnya DBD melalui budaya PSN 3M plus. Struktur G1R1J melibatkan tiga elemen masyarakat, yaitu Jumantik rumah/lingkungan, koordinator Jumantik, dan supervisor Jumantik. Jumantik rumah adalah satu diantara anggota keluarga dalam satu rumah yang bertugas memeriksa dan memantau tempat perkembangbiakan nyamuk di sekitar rumah; mensosialisasikan dan menggerakkan anggota keluarga lainnya untuk melakukan PSN seminggu sekali; mencatat kegiatan tersebut pada lembar kartu jentik. $^{5}$

Kartu jentik merupakan lembaran formulir yang digunakan untuk mencatat hasil pemantauan jentik dan kegiatan 3M plus di rumah/lingkungan. Penelitian di Surabaya dan Aceh Besar menyatakan bahwa penggunaan kartu jentik di setiap rumah/bangunan dapat mempermudah pemeriksaan dan pendataan faktor risiko penularan DBD, ${ }^{6}$ serta membantu masyarakat dalam memantau jentik secara mandiri di lingkungan rumah masingmasing. ${ }^{7,8}$ Kegiatan pengisian kartu jentik oleh Jumantik rumah merupakan salah satu kegiatan surveilans vektor DBD berbasis masyarakat. Diba et al melaporkan bahwa lembar pemantauan jentik mampu membantu pelaksanaan $3 \mathrm{M}$ plus terutama memantau jentik nyamuk secara mandiri di lingkungan rumah. $^{7}$ Hasil kegiatan surveilans ini dapat memberikan gambaran mengenai sebaran risiko berupa kepadatan dan habitat jentik vektor DBD di lingkungan masyarakat. Fournet et al menyebutkan bahwa kegiatan surveilans harus didokumentasikan secara berkala dan diadvokasikan kepada pihak yang berkepentingan sebagai tindakan deteksi dini, epidemiologi dan pemantauan vektor, sehingga dapat menentukan strategi pelaksanaan tata laksana kasus, tindakan pengendalian vektor, dan pemberdayaan masyarakat. ${ }^{9}$ 
Hasil evaluasi Dinas Kesehatan Kota Tangerang Selatan menyebutkan bahwa Puskesmas Pondok Betung dan Puskesmas Pondok Kacang Timur telah menerapkan program G1R1J untuk menekan kasus DBD. Namun pada pelaksanaannya masih ditemukan berbagai kendala. Satu diantara kendala tersebut adalah konsistensi Jumantik rumah (dalam penelitian disebut Jurbastik/Juru Pembasmi Jentik) dalam mengisi kartu jentik sebagai bagian dari kegiatan surveilans DBD berbasis masyarakat. Dampaknya adalah tidak diperoleh data evidence-based yang akurat sebagai Sistem Kewaspadaan Dini (SKD) DBD di wilayah tersebut. Alhasil, kasus DBD masih ditemukan di Puskesmas Pondok Betung dan Pondok Kacang Timur tahun 2019 sebanyak 9 dan 12 kasus. ${ }^{10,11}$ Penelitian Ibrahim dan Quan menyebutkan bahwa kegiatan surveilans entomologi berkontribusi terhadap deteksi dini penularan DBD, sehingga dapat mengevaluasi upaya pengendalian vektor untuk menekan peningkatan kasus DBD. ${ }^{12}$

Berdasarkan uraian tersebut, diperlukan sistem surveilans vektor tingkat rumah tangga yang akurat, sistematis, dan berkelanjutan untuk pengendalian kasus DBD. Evaluasi tentang pemanfaatan dan kepatuhan Jumantik rumah dalam mengisi kartu jentik sebagai upaya surveilans vektor DBD di Tangerang Selatan belum dilakukan. Studi ini bertujuan menganalisis kepatuhan Jumantik rumah dalam mengisi kartu jentik pada wilayah dengan kasus DBD tinggi dan rendah. Informasi ini dapat dimanfaatkan oleh pemegang kebijakan dalam penguatan strategi G1R1J terutama pada wilayah dengan kasus DBD tinggi dan rendah.

\section{METODE}

Studi ini merupakan analisis lanjut dari penelitian "Riset Implementasi Model Juru Pembasmi Jentik (Jurbastik) dalam Penanggulangan DBD (Multicenter 2019)". Persetujuan etik diperoleh dari Komisi Etik Badan Penelitian dan Pengembangan Kesehatan Kemenkes RI nomor:
LB.02.01/2/KE.296/2018. Lokasi penelitian dipilih secara purposif yaitu di daerah endemis DBD yang telah menerapkan program G1R1J minimal sejak tahun 2018. Dua Rukun Warga (RW) terpilih sebagai lokasi penelitian yaitu RW 02 Kelurahan Pondok Betung sebagai wilayah kasus DBD rendah dan RW 09 Kelurahan Pondok Kacang Timur sebagai wilayah kasus DBD tinggi. Populasi penelitian adalah seluruh Jumantik rumah yang bertempat tinggal di kedua wilayah RW tersebut. Sampel penelitian dibagi menjadi dua yaitu sampel data kuantitatif dan kualitatif. Berdasarkan perhitungan sampel Lemeshow diperoleh sebanyak 268 Jumantik rumah untuk dua wilayah RW tersebut. Proporsi responden terdiri dari 137 responden di wilayah Pondok Betung dan 131 responden di wilayah Pondok Kacang Timur. Pemilihan responden dilakukan secara acak sederhana (simple random sampling).

Jumlah informan yang di wawancara mendalam sebanyak 10 informan. Kesepuluh informan tersebut mewakili kriteria rumah tangga yang belum dan pernah ditemukan jentik dirumahnya serta tingkat kepatuhan (tinggi dan rendah) dalam mengisi kartu jentik. Kriteria kepatuhan tinggi yaitu yang selalu mengisi kartu jentik sendiri secara rutin sedangkan kepatuhan rendah adalah yang tidak rutin mengisi kartu jentik. Pertimbangan ini berdasarkan data yang ada di koordinator Jumantik/Kader yang bertanggung jawab di wilayah tersebut

Pengumpulan data kuantitatif menggunakan kuesioner terstruktur dengan wawancara. Sedangkan data kualitatif diperoleh melalui wawancara mendalam menggunakan pedoman wawancara. Data kuantitatif meliputi karakteristik responden (usia dan jenis kelamin), pengetahuan (bentuk, manfaat, dan pihak yang berkewajiban mengisi kartu jentik), sikap (tugas Jurbastik rumah, dan pengisian kartu jentik), tindakan (mengisi, memeriksa, dan mendapatkan sosialisasi mengenai kartu jentik).

Analisis data kuantitatif dianalisis statistik secara bivariat dengan pendekatan uji 
beda Mann Whitney menggunakan aplikasi software open source minitab versi 16 sehingga diperoleh hasil perbedaan antara kelompok kasus DBD rendah dan tinggi berdasarkan variabel pengetahuan, sikap dan tindakan. Data kualitatif di identifikasi SWOT (Strengtness, Weakness, Opportunity, Threat) dan disajikan secara deskriptif.

\section{HASIL}

Karakteristik Responden, Pengetahuan, Sikap, dan Tindakan

Total responden yang berperan serta dikategorikan berdasarkan kategori usia (produktif dan tidak produktif) serta jenis kelamin (laki-laki dan perempuan). Responden pada kedua lokasi penelitian didominasi oleh perempuan dan termasuk kategori usia produktif (Tabel 1).

Tabel 1. Distribusi Karakteristik Responden di Daerah dengan Kasus DBD Rendah dan Tinggi di Kota Tangerang Selatan Tahun 2019

\begin{tabular}{llll}
\hline \multirow{2}{*}{ No. } & Karakteristik & \multicolumn{2}{l}{ Distribusi di wilayah DBD n (\%) } \\
\cline { 3 - 4 } & & $\begin{array}{l}\text { Rendah } \\
\mathrm{N}=137\end{array}$ & $\begin{array}{c}\text { Tinggi } \\
\mathrm{N}=131\end{array}$ \\
\hline 1 & Usia & $102(74,45)$ & $123(93,89)$ \\
& - Produktif & $35(25,55)$ & $8(6,11)$ \\
& - Tidak produktif & & \\
2 & Jenis Kelamin & $22(16,05)$ & $27(20,62)$ \\
& - Laki - laki & $115(83,95)$ & $104(79,38)$ \\
\hline
\end{tabular}

Seluruh variabel pengetahuan dan sikap responden mengenai kartu jentik tidak berbeda nyata antara wilayah kasus DBD rendah dan tinggi. Pada variabel pengetahuan baik di wilayah DBD rendah maupun tinggi terlihat bahwa mayoritas responden mengetahui bentuk tabulasi ( $p$-value 0,101 ) dan manfaat kartu jentik ( $p$-value 0,248 ), tetapi belum mengetahui siapa yang bertugas untuk mengisi kartu jentik (p-value 0,636). Mayoritas responden di kedua wilayah pun setuju apabila kartu jentik diisi setelah pemeriksaan jentik ( $p$-value 0,254), tetapi tidak setuju apabila Jumantik rumah yang bertugas mengisi kartu jentik ( $p$-value 0,636).

Variabel tindakan sebanyak tiga kategori pertanyaan, menunjukkan bahwa seluruh variabel tersebut terdapat perbedaan signifikan antara wilayah kasus DBD rendah dengan kasus DBD tinggi. Responden di wilayah DBD rendah lebih banyak yang pernah mendapatkan sosialisasi kartu jentik dan lebih rutin mengisi kartu jentik dengan $p$ value 0,000 , sedangkan pemeriksaan kartu jentik oleh koordinator Jumantik lebih rutin di wilayah kasus rendah dibandingkan dengan wilayah DBD tinggi ( $p$-value 0,006) (Tabel2). 
Tabel 2. Perbedaan Distribusi Pengetahuan, Sikap, dan Tindakan Mengenai Kartu Jentik di Wilayah Endemis DBD Tinggi dan Rendah Tangerang Selatan tahun 2019

\begin{tabular}{|c|c|c|c|c|}
\hline \multirow{3}{*}{ No. } & \multirow{3}{*}{ Variabel } & \multicolumn{2}{|c|}{ Distribusi di daerah kasus DBD n(\%) } & \multirow{3}{*}{ p-value } \\
\hline & & Rendah & Tinggi & \\
\hline & & $\mathrm{N}=137$ & $\mathrm{~N}=131$ & \\
\hline \multirow[t]{10}{*}{1} & Pengetahuan & & & \\
\hline & Bentuk/susunan tabulasi kartu jentik & & & 0,101 \\
\hline & - Tahu & $98(71,54)$ & $80(61,06)$ & \\
\hline & - Tidak tahu & $39(28,46)$ & $51(38,94)$ & \\
\hline & Manfaat kartu jentik & & & 0,248 \\
\hline & - Tahu & $93(67,88)$ & $77(58,77)$ & \\
\hline & - Tidak tahu & $44(32,12)$ & $54(41,23)$ & \\
\hline & Pihak yang dapat mengisi kartu jentik & & & 0,145 \\
\hline & - Tahu & $47(34,31)$ & $32(24,43)$ & \\
\hline & - Tidak tahu & $90(65,69)$ & $99(75,57)$ & \\
\hline \multirow[t]{7}{*}{2} & Sikap & & & \\
\hline & $\begin{array}{l}\text { Satu diantara tugas Jumantik rumah adalah } \\
\text { mengisi kartu jentik }\end{array}$ & & & 0,254 \\
\hline & - Setuju & $21(15,33)$ & $13(9,93)$ & \\
\hline & - Tidak setuju & $116(84,67)$ & $118(90,07)$ & \\
\hline & $\begin{array}{l}\text { Kartu jentik diisi setelah melakukan pemeriksaan } \\
\text { jentik }\end{array}$ & & & 0,636 \\
\hline & - Setuju & $129(94,16)$ & $122(93,13)$ & \\
\hline & - Tidak setuju & $8(5,84)$ & $9(6,87)$ & \\
\hline \multirow[t]{10}{*}{3} & Tindakan & & & \\
\hline & Kartu jentik diisi secara rutin & & & $0,000 *$ \\
\hline & - Diisi secara rutin & $88(64,24)$ & $45(34,35)$ & \\
\hline & - Tidak diisi secara rutin & $49(35,76)$ & $86(65,65)$ & \\
\hline & Kartu jentik diperiksa secara rutin & & & $0,006^{*}$ \\
\hline & - Diperiksa secara rutin & $135(98,55)$ & $120(91,61)$ & \\
\hline & - Tidak diperiksa secara rutin & $2(1,45)$ & $11(8,39)$ & \\
\hline & $\begin{array}{l}\text { Pernah mendapatkan sosialisasi cara mencatat di } \\
\text { kartu jentik }\end{array}$ & & & $0,000 *$ \\
\hline & - Pernah & $85(62,05)$ & $12(9,16)$ & \\
\hline & - Tidak pernah & $52(37,95)$ & $119(90,84)$ & \\
\hline
\end{tabular}

*signifikan $(p$-value $<0,05)$

\section{Identifikasi SWOT Mengenai Kepatuhan Jumantik Rumah dalam Mengisi Kartu Jentik}

Karakteristik usia informan termuda 32 tahun, sedangkan tertua 79 tahun, tingkat pendidikan bervariasi mulai dari tidak tamat SD sampai Sarjana (S1). Pengumpulan data kualitatif melalui beberapa tahapan yaitu perekaman hasil wawancara; cleaning data; transkripsi; selanjutnya matriks isi untuk melihat isi dari tiap topik yang ingin diamati. Data dari informan divalidasi dengan melakukan triangulasi sehingga data yang terkumpul telah menjawab tema/topik serta tercapai saturated data (kejenuhan).
Hasil wawancara mendalam diketahui bahwa sumber informasi mengenai cara pengisian kartu jentik telah diterima oleh sebagian besar informan dari koordinator Jumantik dan buku panduan. Koordinator Jumantik menyampaikan pengetahuan tentang tempat-tempat perkembangbiakan jentik dan tata cara mengisi kartu jentik seperti penuturan informan di wilayah kasus DBD rendah berikut ini:

"dari kader ada...selalu ada...iya, dijelaskan dan saya pun juga membaca (buku panduan) ya melihat..seperti itu.."(J/ 56 tahun) 
"Ya cara membersihkan tempat-tempat yang dibersihkan.. cara mengisinya kan sesuai tempat-tempat yang di bersihkan..".(L/34 tahun)

Salah satu tugas Jumantik rumah selain memantau dan membasmi keberadaan jentik di rumahnya adalah melakukan pencatatan kegiatan pemantauan jentik yang telah dilakukan. Ada beberapa Jumantik rumah yang rajin mengisi setiap selesai melakukan pemantauan, tetapi ada beberapa yang mengalami kendala sehingga tidak mengisi kartu jentik secara rutin. Sebagian besar Jumantik rumah menyatakan bahwa faktor tidak mengisi kartu jentik adalah lupa karena faktor kesibukan lainnya. Hal ini sesuai dengan penuturan informan berikut ini :

“Ada ...diisi oleh sendiri ..... Ya kalo dah rampung dah bersih ya coret.. jadi kader tinggal tanda tangan.. "(S/32 tahun)

Beberapa kendala yang disebutkan para informan adalah kurangnya sarana alat tulis, Jumantik rumah berusia lanjut dan penglihatan, kesibukan sehari-hari, dan lupa. Untuk mengatasi kendala tersebut keluarganya untuk membantu pencatatan pada kartu pemeriksaan jentik. Hal itu sesuai penuturan para informan sebagai berikut:

"Kalo yang udah tua emang harus di bantu di bacain sama kader kadernya ikut bantu bantu periksa terus udah di cek belum udah dibersihin belum..kasihan juga ga bisa baca ga bisa nulis jadi harus di bantu"(S/32 Tahun)

"Apalagi kalau banyak kegiatan. kadangkadang yaa...ini kan di luar yaa..lupa...ini aja kayaknya dari kemarin belum ditulis.. "(P/53 tahun)

“...Yang nyatet mantu saya...” (T/60 tahun)

Hasil analisis wawancara mendalam terkait SWOT disajikan secara deskriptif dan dikelompokkan dalam 4 komponen SWOT. Komponen kekuatan (Strengthness) dan peluang (Opportunities) menjadi pengaruh positif sebagai potensi dan motivasi kepatuhan Jumantik rumah dalam melaksanakan tugas sebagai bentuk upaya pengendalian vektor DBD di rumah dan lingkungan sekitarnya. Walaupun masih ada komponen kelemahan (Weakness) dan ancaman (Threats) yang menjadi pengaruh negatif (Tabel 3).

Tabel 3. Identifikasi SWOT Kepatuhan Jurbastik dalam Mengisi Kartu Jentik di Tangerang Selatan Tahun 2019

\begin{tabular}{|c|c|c|}
\hline No & Komponen & Uraian \\
\hline 1 & Strengthness & $\begin{array}{l}\text { 1. Koordinator Jumantik melakukan kunjungan dan sosialisasi secara rutin } \\
\text { kepada Jumantik rumah } \\
\text { 2. Jumantik rumah telah memahami manfaat kartu jentik } \\
\text { 3. Jumantik rumah memiliki kartu jentik dan buku panduannya } \\
\text { 4. Mayoritas jumantik rumah adalah perempuan usia produktif }\end{array}$ \\
\hline 2 & Weaknesses & $\begin{array}{l}\text { 1. Jumantik rumah relatif belum mengetahui cara mengisi kartu jentik } \\
\text { dengan benar } \\
\text { 2. Kesibukan kerja Jumantik rumah } \\
\text { 3. Faktor usia dan kelemahan fisik (mata) Jumantik rumah } \\
\text { 4. Jumantik rumah sering lupa untuk mengisi kartu jentik }\end{array}$ \\
\hline 3 & Opportunities & $\begin{array}{l}\text { 1. Jumantik rumah dapat melibatkan anggota rumah tangga yang lainnya } \\
\text { untuk mengisi kartu jentik } \\
\text { 2. Jumantik rumah dapat berkonsultasi dengan Koordinator Jumantik } \\
\text { mengenai cara mengisi kartu jentik yang benar } \\
\text { 3. Dukungan tokoh masyarakat untuk mengingatkan dalam forum-forum } \\
\text { informal }\end{array}$ \\
\hline 4 & Threats & 1. Masih adanya masyarakat yang belum mau ikut berperan dalam G1R1J \\
\hline
\end{tabular}




\section{PEMBAHASAN}

Kartu jentik merupakan instrumen penting dalam program Gerakan Satu Rumah Satu Jumantik (G1R1J). Berdasarkan Petunjuk Teknis Implementasi G1R1J, kartu jentik berfungsi sebagai media pelaporan kegiatan surveilans berbasis masyarakat. Kartu jentik diisi secara rutin satu minggu sekali oleh Jumatik rumah. Hasil pencatatan oleh Jumantik rumah ini kemudian direkap oleh koordinator Jumantik untuk dilaporkan ke supervisor Jumantik. Hasil pemeriksaan jentik ini selanjutnya dianalisis dan dijadikan sebagai evidence-based kepadatan vektor. ${ }^{5}$ Jika merujuk pada petunjuk teknis ini, pengisian kartu jentik oleh Jumantik rumah dalam rangka pengawasan kesehatan masyarakat telah sesuai dengan prinsip surveilans berbasis masyarakat. Guerra J. et al menjabarkan surveilans berbasis masyarakat sebagai suatu upaya penanggulangan penyakit dengan melibatkan masyarakat secara langsung untuk mengidentifikasi dan melaporkan situasi kesehatan di lingkungannya dalam rangka pengawasan kesehatan masyarakat. ${ }^{13}$ Data yang diperoleh tersebut dapat menjadi bahan early warning system DBD di wilayah tersebut. Ong J. et al menyatakan bahwa identifikasi kepadatan jentik di masyarakat dapat memprediksi epidemi virus Dengue yang ditularkan oleh Aedes sp. ${ }^{14}$

Berdasarkan hasil analisis data kuantitatif terlihat bahwa mayoritas Jumantik rumah dikedua wilayah telah mengetahui bentuk/susunan dan manfaat kartu jentik sebagai media pencatatan hasil pemeriksaan jentik. Hal ini dikarenakan kedua wilayah tersebut telah menerapkan program G1R1J, sehingga setiap bangunan rumah memiliki kartu jentik. Namun pembagian kartu jentik tampaknya tidak disertai dengan penjelasan tugas seorang Jumantik rumah yaitu melakukan pemantauan dan pencatatan pada kartu jentik hasil pemantauan yang dilakukan, sehingga pengetahuan Jumantik rumah tentang tugas mengisi kartu jentik masih sedikit di kedua wilayah.
Mayoritas Jumantik rumah belum mengetahui tugas Jumatik rumah yang salah satunya adalah mengisi kartu jentik, sehingga Jumantik rumah bersikap tidak setuju untuk mengisi kartu jentik setelah melakukan pemantauan di rumahnya. Hal ini menyebabkan rendahnya kepatuhan untuk mengisi kartu jentik secara rutin. Sebagian Jumantik rumah di kedua wilayah masih menganggap bahwa tugas pencatatan pada kartu jentik adalah tugas koordinator Jumantik. Hasil yang sama dengan penelitian di Yogyakarta, menyatakan bahwa kesibukan Jumantik rumah, menjadi alasan sehingga kartu jentik diisi koordinator Jumantik. ${ }^{8}$ Hal ini berdampak pada bertambahnya tugas koordinator Jumantik dalam menggerakkan para Jumantik rumah untuk melaksanakan tugas dan fungsinya. ${ }^{15,16}$

Alasan lain tidak mengisi kartu jentik antara lain Jumantik rumah tidak memiliki alat tulis, usia lanjut, membutuhkan alat bantu penglihatan, kesibukan pekerjaan, dan lupa mengisi. Jumantik rumah yang sudah berusia lanjut merasa kesulitan untuk mengisi karena sudah berkurangnya kemampuan melihat. Selain itu, Jumantik rumah yang memiliki kesibukan di luar sering lupa untuk mengisi kartu jentik meskipun telah melaksanakan kegiatan pemantauan jentik di rumahnya. Hal ini merupakan faktor internal yang dapat diatasi dari diri Jumantik rumah tersebut. Beberapa Jumantik rumah melibatkan menantu, anak atau anggota keluarga lain untuk membantu pencatatan. Hal tersebut menunjukkan untuk mengatasi kelemahannya Jumantik rumah memerlukan motivasi dan bimbingan untuk menemukan solusi. Hasil ini menunjukkan bahwa selain tingkat pengetahuan, faktor motivasi dalam diri Jumantik rumah juga berperan dalam kepatuhan mengisi kartu jentik. Peningkatan motivasi memberikan pengaruh terhadap peningkatan upaya pengendalian Aedes spp. oleh warga. ${ }^{6,17}$

Penelitian di Aceh dan Malaysia menyimpulkan bahwa pengetahuan dapat mempengaruhi tindakan seseorang dalam 
pencegahan DBD. ${ }^{18,19}$ Penelitian Diba dan Farkhan juga menyatakan bahwa tingkat pengetahuan yang baik berhubungan dengan perubahan sikap kepedulian seseorang terhadap pengisian lembar pemantauan jentik $(\mathrm{p}<0,05) .{ }^{7}$ Kurangnya pengetahuan tentang tugas Jumantik rumah mempengaruhi motivasinya mengisi kartu jentik. Merujuk pada teori perilaku kesehatan mengungkapkan bahwa pengetahuan dan sikap seseorang merupakan hubungan timbal balik dalam membentuk motivasi seseorang untuk bertindak. ${ }^{20}$ Masyarakat yang memiliki pengetahuan yang kurang baik cenderung mempunyai motivasi yang kurang. Sebaliknya, apabila tingkat pengetahuannya baik, maka akan menjadi motivasi untuk bersikap lebih baik.

Ketidaktahuan Jumantik rumah terhadap siapa yang berperan dalam pengisian kartu jentik mengindikasikan belum tersosialisasikannya tugas seorang Jumantik rumah secara utuh kepada masyarakat. Dalam kunjungan rutinnya, sosialisasi tugas Jumantik rumah dilakukan oleh koordinator Jumantik. Sosialisasi ini meliputi penyampaian informasi mengenai tempat perkembangbiakan nyamuk, cara pemantauan jentik dan tata cara pengisian kartu jentik. Koordinator Jumantik harus memiliki competent credibility yang didapatkan melalui pelatihan keterampilan dan safety credibility yaitu sebagai seseorang yang dapat dipercaya masyarakat, ${ }^{6}$ sehingga sosialisasi yang di sampaikan bisa dipahami oleh para Jumantik rumah.

Hasil analisis ini juga memberikan gambaran bahwa meskipun tidak terdapat perbedaan bermakna tingkat pengetahuan dan sikap responden mengenai kartu jentik di kedua lokasi, namun tindakan responden mengenai kepatuhan mengisi kartu jentik berbeda antara wilayah kasus DBD tinggi dengan kasus DBD rendah. Tingkat kepatuhan Jumantik rumah di wilayah kasus DBD rendah lebih tinggi dibandingkan wilayah kasus DBD tinggi. Perbedaan ini diduga karena frekuensi kunjungan koordinator Jumantik di wilayah dengan kasus DBD rendah lebih tinggi dibandingkan wilayah DBD tinggi. Hasil wawancara mendalam di wilayah DBD rendah menunjukkan bahwa para Jumantik rumah yang rutin mengisi kartu jentik mendapatkan penyuluhan dari koordinator Jumantik dalam kunjungan rutinnya. Informasi yang diterima mengenai tempat-tempat perkembangbiakan jentik serta cara pengisian kartu jentik. Peran koordinator Jumantik sangat besar dalam mempengaruhi kepatuhan Jumantik rumah mengisi kartu jentik. Koordinator Jumantik harus memiliki ragam keterampilan komunikasi untuk dapat memberikan pemahaman teknis kepada Jumantik rumah yang berusia muda dan tua, wanita karier dan ibu rumah tangga, baik yang sudah maupun belum memiliki kesadaran mengenai G1R1J. Pada umumnya, anjuran dari koordinator Jumantik yang dalam hal ini adalah kader kesehatan dapat mempengaruhi tindakan masyarakat untuk berpartisipasi dalam pemberantasan DBD. ${ }^{15}$

Kunjungan rutin koordinator Jumantik ke rumah binaanya menjadi kekuatan sendiri dalam kepatuhan Jumantik rumah mengisi kartu jentik. Potensi ini dapat ditingkatkan dengan meningkatkan frekuensi kunjungan koordinator Jumantik dan meningkatkan kualitas koordinator Jumantik dalam melakukan pembinaan, dengan kunjungan rutin ini, Jumantik rumah akan memahami tugasnya dengan baik serta mendapatkan solusi jika ditemukan masalah dalam menjalankan tugasnya. Kunjungan koordinator Jumantik juga mampu meningkatkan motivasi untuk melakukan pengisian secara rutin. Potensi lainnya adalah mayoritas Jumantik rumah di kedua daerah berjenis kelamin perempuan dengan usia produktif. Pekerjaan memantau jentik dan melakukan pencatatan dapat dikategorikan sebagai pekerjaan domestik yang ranahnya lebih banyak dilakukan oleh perempuan. ${ }^{21,22}$ Mobilisasi perempuan sebagai masyarakat potensial dalam memberantas sarang nyamuk dapat menjadi potensi besar untuk penanggulangan DBD karena dapat mengurangi faktor risiko penularan penyakit. ${ }^{23}$ 


\section{KESIMPULAN}

Tingkat kepatuhan dalam mengisi kartu jentik di wilayah kasus DBD rendah lebih tinggi dibandingkan pada wilayah kasus tinggi. Kendala dalam pengisian kartu jentik adalah faktor kurangnya sarana, usia lanjut, kelemahan penglihatan, kesibukan, dan lupa.

\section{SARAN}

Masih kurangnya pengetahuan terhadap tugas Jumantik rumah serta masih rendahnya motivasi yang dimiliki oleh Jumantik rumah di duga menjadi penyebab munculnya kendala pengisian kartu jentik. Peningkatan frekuensi dan kualitas koordinator Jumantik dalam membina rumah binaannya diharapkan bisa menjadi solusi dalam meningkatkan kepatuhan penulisan kartu jentik.

\section{KONTRIBUSI PENULIS}

HF, HP dan EPA sebagai kontributor utama dan bertanggung jawab dalam menyusun konsep, analisis data, koleksi referensi, menulis, dan koordinasi.

\section{UCAPAN TERIMA KASIH}

Terima kasih penulis ucapkan kepada kepala Badan Penelitian dan Pengembangan Kesehatan dan Kepala Loka Litbang Kesehatan Pangandaran yang telah memberikan kesempatan penulis untuk dapat melaksanakan studi ini. Terima kasih juga kami sampaikan kepada Dinas Kesehatan Kota Tangerang Selatan atas kerjasama yang baik. Ucapan terima kasih juga kami sampaikan kepada teman-teman peneliti dan teknisi yang telah melaksanakan penelitian ini

\section{DAFTAR PUSTAKA}

1. Bhatt S, Gething PW, Brady OJ, Messina JP, Farlow AW, Moyes CL, et al. The global distribution and burden of dengue. Nature. 2013;496(7446): 504-7.

2. Jentes ES, Lash RR, Johansson MA, Sharp TM, Henry R, Brady OJ, et al. Evidencebased risk assessment and communication: a new global dengue-risk map for travellers and clinicians. J Travel Med. 2016;23(6). doi:10.1093/jtm/taw062.

3. Messina J, Brady O, Scott T. Global spread of dengue virus types: mapping the 70 year history. Trends Microbiol. 2014;22:138-46.

4 Dinas Kesehatan Kota Tangerang Selatan. Data Kasus DBD tahun 2017-2019. Tangerang Selatan; 2019.

5. Dirjen P2P Kemenkes RI. Petunjuk teknis implementasi PSN 3M - plus dengan gerakan 1 rumah 1 jumantik. Jakarta: Kementerian Kesehatan RI; 2016.

6. Agustini RT. Evaluasi pemeriksaan jentik berkala rumah warga di wilayah Puskesmas Tanah Kalikedinding Surabaya (periodic larva inspection evaluation in Tanah Kalikedinding Public Health Center). J Promkes. 2015;3: 195-205.

7. Diba F, Farkhan. Pilot studi: efektifitas penerapan lembar pemantauan jentik nyamuk Aedes aegypti secara mandiri di Desa Lampuja, Aceh Besar. Idea Nurs J. 2017;8(2):63-72.

8. Sulistyawati S, Astuti FD, Umniyati SR, Satoto TBT, Lazuardi L, Nilsson $\mathrm{M}$ et al. Dengue vector control through community empowerment: lessons learned from a community-based study in Yogyakarta, Indonesia. Int J Environ Res Public Health. 2019;16(6):1013.

doi:10.3390/ijerph16061013.

9. Fournet F, Jourdain F, Bonnet E, Degroote S, Ridde V. Effective surveillance systems for vector-borne diseases in urban settings and translation of the data into action: a scoping review. Infect Dis Poverty. 2018;7(99). doi:10.1186/s40249-018-0473-9.

10. Puskesmas Pondok Betung. Data DBD Puksemas Pondok Betung Tahun 2016-2019. Tangerang Selatan; 2019.

11. Puskesmas Pondok Kacang Timur. Data Kasus DBD Puskesmas Pondok Kacang Timur Tahun 2016-2019. Tangerang Selatan; 2019.

12. Ibrahim N, Quan TW. The development of multi-platforms application for dengueentomological surveillance system. In:6th ICT International Student Project Conference: Elevating Community Through ICT; 2017. ICT-ISPC;2017. p.1-4. 
13. Guerra J, Acharya P, Barnadas C. Community-based surveillance: a scoping review. PLoS One. 2019;14(4):e0215278. doi:10.1371/journal.pone.0215278.

14. Ong J, Liu X, Rajarethinam J, Yap G, Ho D, $\mathrm{Ng}$ LC. A novel entomological index, Aedes aegypti breeding percentage, reveals the geographical spread of the dengue vector in Singapore and serves as a spatial risk indicator for dengue. Parasites and Vectors. 2019;12(17). doi:10.1186/s13071-018-3281$\mathrm{y}$.

15. Puspareni NL, Patra IM, Rusminingsih NK. Pengaruh faktor-faktor derteminan terhadap partisipasi masyarakat dalam pemberantasan sarang nyamuk demam berdarah dengue di Kelurahan Panjer Tahun 2012. J Kesehat Lingkung. 2012;4:70-4.

16. Adnan AB, Siswani S. Peran kader jumantik terhadap perilaku masyarakat dalam upaya pencegahan penyakit Demam Berdarah Dengue (DBD) di wilayah kerja Kelurahan Tebet Timur Tahun 2019. Jukmas. 2019;3(2):204-18.

17. Prasetyowati H, Santya RNRE, Nurindra RW. Motivasi dan peran serta masyarakat dalam pengendalian populasi Aedes spp. di Kota Sukabumi. J Ekol Kesehat. 2015;14(2):10615 .
18. Wong LP, Shakir SMM, Atefi N, AbuBakar S. Factors affecting dengue prevention practices: nationwide survey of the Malaysian public. PLoS One. 2015;10(4):e0122890. doi:10.1371/journal.pone.0122890.

19. Harapan H, Rajamoorthy Y, Anwar S, Bustamam A, Radiansyah A, Angraini P, et al. Knowledge, attitude, and practice regarding dengue virus infection among inhabitants of Aceh, Indonesia: A crosssectional study. BMC Infect Dis. 2018;18(96). doi:10.1186/s12879-018-3006-Z

20. Notoatmodjo S. Ilmu perilaku kesehatan. Jakarta: Rineka Cipta; 2010.

21. Harun ARMQ. Rethinking Peran perempuan dalam keluarga. Karsa J Sos dan Budaya Keislam. 2015;23(1):17-35. doi:10.19105/karsa.v23i1.607

22. Zahrok S, Suarmini NW. Peran perempuan dalam keluarga. IPTEK J Proc Ser. 2018;(5):61-5.

23. Bardach A, Belizán M, Ciapponi A. Emerging viruses: a view from the south interventions to control Aedes aegypti in Latin America and the Caribbean. ISAR News Off Publ Int Soc Antivir Res. 2018; 28:31-2. 